\title{
TEACHING SPEAKING OF HOTEL ROOM SERVICE INFORMATION BY USING COMIC STRIP VIA GOOGLE MEET APPLICATION
}

\author{
${ }^{\# 1}$ Putu Ngurah Rusmawan, ${ }^{* 2}$ Ely Trianasari, ${ }^{* 3}$ Ninik Sri Rahayu Wilujeng \\ ${ }^{\# 1}$ English Lecturer, Tourism Business Management, Politeknik Negeri Banyuwangi, \\ Indonesia \\ ${ }^{* 2}$ English Lecturer, Engineering, Politeknik Negeri Banyuwangi, Indonesia \\ ${ }^{*}$ Lecturer, Live Stock Processing, Politeknik Negeri Banyuwangi, Indonesia
}

Corresponding Author Email: putungurahrusmawan@poliwangi.ac.id

\begin{abstract}
A B S T R A C T S
During Covid 19 teaching and learning should be conducted via an online system. One of the supporting tools is using the application of google meet. The student in the tourism business management department must able to speak English in descriptive text fluently. The students must be provided excellent English skills to escort and to explain the clear hotel room facilities and services for international guests. The comic strip is teaching media that is suitable in-state polytechnic of Banyuwangi because it can help the student to understand the text easily. The lecturer tried to describe the teaching speaking activity in the classroom using the google meet platform. The study used a descriptive qualitative research design. The researcher analyzed and described the teaching speaking in the descriptive text by using comic strip for the tourism department. The preparation of the lecturer was syllabus and course agreement which consist of learning objective and indicator, the method, and learning sources. The lecturer taught the students based on course agreement. The lecturer only facilitated the students to be active in speaking descriptive text. He asked the students to do modeling communication in a hotel. One of the students performed as a bell boy and the other as a tourist who wants to stay in a hotel. During the teaching-learning process, the lecturer got three main troubles in conducting the teaching process. There was students' low in vocabulary, pronunciation, losing signal, and trouble in expressing sentences. Speaking descriptive text course which was taught by the lecturer proceeded effectively and acceptable for the students.
\end{abstract}

A R T I C L E I N F O

Article History:

Received: April, 2021

Revised: May, 2021

Published: June, 2021

\section{Keywords:}

Comics Strip,

Speaking,

Descriptive Text,

Google Meet Application,

How to cite: Rusmawan, P., Trianasari, E., \& Wilujeng, N. (2021). Teaching Speaking of Hotel Room Service Information by Using Comic Strip via Google Meet Application. Jo-ELT (Journal of English Language Teaching) Fakultas Pendidikan Bahasa \& Seni Prodi Pendidikan Bahasa Inggris IKIP, 8(1), 3848. doi:https://doi.org/10.33394/jo-elt.v8i1.3708

\section{INTRODUCTION}

Mastering English for international communication is a must for students in the D-4 tourism business department of Politeknik Negeri Banyuwangi. English is an international system of communication that can help to open the investment of business and tourism communication. One of the English proficiency that was compulsory to be learned by the tourism department was speaking skills. The main objective of teaching English especially 
speaking skills is to enable students to use the language effectively. In teaching speaking skills the main target is the students who are able to use the language properly.

Speaking skill is the students' ability to express their ideas orally which is represented in the students' minds. According to Nunan (2003) states that speaking ability was more complex and more difficult than people assume and speaking study like study other cases in the study of language. In speaking class, lecturers are required to create a communicative and interactive atmosphere actively by giving students plenty of opportunities to practice the target language. The class should be focused on student-centered

Since March 2020, Corona Virus disease 19 was spread out worldwide. It had been already one year. Many students and teachers over the world avoided offline classroom meetings. The classroom teaching and learning process should be on an online system. One of the online applications that were used to make classroom interaction was google meet. It was the alternative applications that enable to teach of speaking skills descriptive text. Using the google meet application, the lecture can share the screen of the comic strip about the conversation in a hotel room and the restaurant. The comic strip was believed that could help the students to speak descriptive fluently (Merc, 2013). It could open high creative speaking descriptive text.

Transactional communication in tourism is motivated by an exchange of goods and services, for example, booking a flight at a travel agent, whereas the motivation for interactional communications primarily to create and maintain a social relationship, for example, casual conversation between friends (Brown, 2007). According to Harmer (2007), there are some themes selected in teaching speaking are suggested to follow the following sequence, one of them is the topic on social activities, either interpersonal (social interaction), or transactional (getting things done) types, e.g: talking about the trip to tourism object, expressing of agreement or disagreement, expressing of happiness or sadness, inviting and accepting/refusing an invitation, etc.

Based on the course agreement for teaching speaking in the D-4 tourism business management department in Politeknik Negeri Banyuwangi, the students are expected to speak descriptive text about hotel service information fluently. Tourism business management students at Politeknik Negeri Banyuwangi must able to serve international guests well. The students also can do the transactional and interpersonal activities better, they can express the complex meaning by speaking descriptive text.

The purpose of this study is to know the teaching process by using comic strips to teach the students' speaking ability in the tourism business management department of Politeknik Negeri Banyuwangi via the google meet application. The researcher chooses the student in first grade of class B of Politeknik Negeri Banyuwangi because based on the information from the lecture they are the best students speaking. The researcher focused on teaching and learning activities as the subject of the study. The expressions that will be emphasized in this study are about ordering something, hotel room facility, and room service restaurant.

This study aims to focus more on the teaching and learning strategy in using the online system google meet rather than the formation of students during performing students speaking activities in descriptive text offline. Therefore, using the google meet application can promote meaningful interaction between the learners and as a result can help to enrich their language production.

\section{RESEARCH METHOD}

This section described how to get the data information of lecturer and students activities during learning speaking descriptive text hotel information system by using comic strip. 


\section{Research Design}

The research design of the study was a descriptive qualitative design. Susanto (2010), stated that case study research used a qualitative research design that the researcher should explore and found the depth data collection. It contained the sources of information (for example, observation, interviews, audiovisual material, documents, and reports), and reports a case description and case-based themes. In this study, the researcher observed the teaching speaking by using comic strip in business tourism management at Politeknik Negeri Banyuwangi via google meet application.

\section{Subject}

The subject of the study is the first grade of students from tourism business management at Politeknik Negeri Banyuwangi. The researcher chooses tourism business management at Politeknik Negeri Banyuwangi. The lecturer stated that students understand the material by given using comic strips via the google meet application. The researcher took first-semester students and the lecturer as the subject of the study. There were 25 students in this class; 10 males and 15 females and the English lecturer.

\section{Instruments}

The instruments used in this research were observation, questionnaire, interview, and documentation. According to Susanto (2010) observation is the process of gathering first source information by observing people and places at a research site. Bogdan and Biklen (2007) stated that the observation checklist is most often used to evaluate the descriptive that a teacher used during classroom teaching. An actual observer is unremarkable and makes some notes based on everything that the observer saw. The researcher can make the evaluations and also gives the lecturer an idea. The researcher needed an observation on the English lecturer of the first semester students. During the teaching-learning process, he obtained data by joining the link of the google meet application and he took note of every conversation and event that had been occurred during classroom daring interaction. Here, the researcher wanted to know the fact and the real data about the teaching speaking in terms of the descriptive of the lecturer's preparations in teaching speaking, the difficulties that the students had in speaking, and the way the lecturer in overcoming the students' speaking problem at Politeknik Negeri Banyuwangi. According to Susanto (2010), a questionnaire is a form used in a survey design that participants in a study complete and return to the researcher. The participants choose answers to questions and supply basic personal or demographic information. The types of the questionnaire that the researcher used were dichotomous questions and open-ended questions which allowed the students to answer a yes-no question and let them give their reason for each their answer. In this case, the researcher will give 10 questions to the students about teaching-learning speaking by using the google meet application.

According to Susanto (2010), the interview process happened when researchers asked someone or more participants general, open-ended questions and record their answer. The researcher will do an informal interview with the English lecturer in Politeknik Negeri Banyuwangi to know the teaching-learning process by using the google meet application in teaching speaking. The interview activity will be conducted after the teaching-learning activity.

According to Creswell (2013), documents consist of public and private records that qualitative researchers obtain about a site or participants in a study, and they can include newspapers, minutes of meetings, personal journals, and letters. The document collected in this research was the lecturer's preparation, such as syllabus, course agreement, and students' worksheet. 


\title{
Data Analysis
}

The data of the research would be analyzed through some steps, questionnaires were calculating to answers the research question. The interview transcription will be collected, reduced, and selected based on research that must be answered the research question. An observation guide would be the result of the checklist for the classroom activity via an online system. The researcher also analyzed lecturer documentation interpreted the course agreement, and the students' worksheet the speaking, the researcher analyzed the lecturer evaluation on the students' achievement in speaking descriptive text and concluding based on the data analysis above.

The data taken from observation and interview were analyzed directly by giving discussion and related it with a review of related literature. On other hand, data taken from the questionnaire were analyzed using the formula in figure 1.

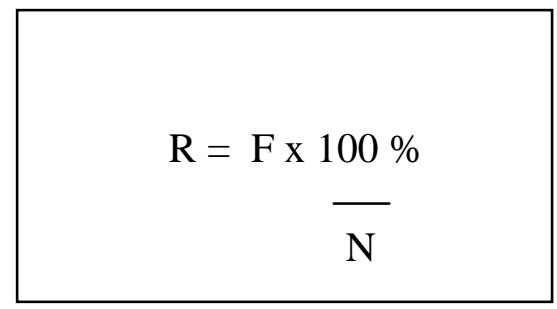

Figure 1. The Formula of Calculation The Students' Questionnaire

(Source: Arikunto, 2008)

\author{
Note: \\ $\mathrm{R}=$ Students respond \\ $\mathrm{F}=$ Frequency of students' respond \\ $\mathrm{N}=$ The number of students
}

\section{RESEARCH FINDINGS AND DISCUSSION}

This section presents the findings and the discussion of the research. The findings were based on the observation checklists and the questionnaire. The data were related to the student's activities during the teaching and learning process. The discussion provides information on how the lecturer taught speaking skills in the descriptive text by using comic strip via google meet application.

\section{Research Findings}

The findings were completed by the supporting data. In this part, the researcher explained the process and findings of the research. The aim of this study is to investigate the fact that has occurred in teaching descriptive text by using the comic strip as media at Politeknik Negeri Banyuwangi. There were two meetings that had been done on January $4^{\text {th }}$ and $11^{\text {th }}, 2021$. The first meeting was implementing the teaching of speaking descriptive text by using comic strip. The second meeting was reviewing the material and giving a test.

The plan consisted of teaching-learning items, such as the material, the media, and the course agreement. The material was descriptive and the theme was hotel service information and room facility. The media, the researcher used comic strip as media in teaching descriptive text. The course agreement was prepared by the lecturer, consists of (a) the subject, course description, semester, academic year, and time allotment, (b) the objective of the course agreement that was at the end of the teaching and learning process, the students were able to get information from guiding question to make about hotel room facilities text by using comic strip, the students were able to respond orally about hotel information system and by using comic strip, students were able to do transaction dialogue based on the information in 
the comic strip, (c) the teaching-learning process was divided into some phases, they were opening, main activity, and closing, (d) the source was taken from a book and the internet, (e) The oral test was chosen by the researcher as the evaluation.

The first meeting was used for teaching speaking by implementing comic strip as media in teaching-learning. The second meeting was reviewing the material and conducting a test.

\section{Meeting I}

The first meeting was conducted on January $4^{\text {th }}, 2021$. Based on the time allocation in the course agreement, this meeting was held for 90 minutes or $2 \times 50$ minutes. It started at 09.00-10.30 AM. At the end of the lesson, the students were expected to be able to get information from the guiding question to make a hotel facilities description based on the comic strip; students were able to respond orally by using comic strip students were able to do the transaction dialogue based on the information in the comic strip about hotel service information.

\section{Pre Activity}

This activity was carried out in 15 minutes. There were steps in this section. First, the lecturer asked the students to pray together. Then, she checked the students' attendance and introduces herself. After that, the lecturer told the objective of the course agreement and stimulated the students about the topic that would be discussed and the media comics strip that would be used.

\section{Whilst Activity}

Whilst activity was carried out in 65 minutes, whilst activity divided some parts first, the lecturer gave brainstorming by using comic strips around the room hotel about vocabularies which related to the lesson. Second, she described the room facility. Then, the lecturer explained about description text. After that, the lecturer asked the students to make some groups then the students should look for the comic strips on their screen to discuss together a. Next, the lecturer gave the task by answering the guiding question based on the worksheet, and then the lecturer controlled the students' activity in giving information and making descriptions. After that, the lecturer asked some students to describe their online assignments via the google meet application. In the last section, the lecturer gave corrections about their description.

After giving brainstorming, the lecturer continued whilst activity by describing the hotel service information about the room facility. After that, the lecturer explained descriptive text. After explaining about description text, the researcher asked the students to make some groups based on students' preference, then the students should look for the room related to their screen. After that, the researcher gave the task by answering the guiding question based on the worksheet. The researcher controlled the students' activity in giving information and making descriptions. The researcher controlled them when asking the question and making the description.

While the researcher was observing the students who were doing the conversation, the researcher found out they had difficulty in arranging words to speak and most of their pronunciation was poor. After the conversation was finished, the researcher discussed the guiding question. She stimulated the students to speak up by answering guiding questions such as, "How about the bedroom size in this room?"

In the last section of whilst activity was, the researcher asked some students to explain their descriptions in google meet then the lecturer gave corrections about their descriptions. The students presented their descriptions. Another student who did not present should give the question to the presenter. Most of them were reluctant to ask questions because they were 
not confident to speak English. After that, the researcher gave feedback to the students by giving the correction toward their pronunciation and grammar usage.

\section{Post Activity}

This activity was carried out in 10 minutes. In this activity, the lecturer asked about the material and difficulties during the teaching-learning process and making a conclusion. During the classroom activities via the google meet application above, the observer that was the English lecturer of tourism business management filled the observation checklist to know how far the students' enthusiasm while the teaching and learning process that was found in the meeting I.

\section{Observation}

In this case, the researcher used some instruments to know about the student's attitude toward the use comic strip as media in this study. The instruments were observation checklist, questionnaire, and the students' achievement or the result of the students' test that each of them was explained in more detail as follows.

\section{The Result of the Observation Checklist meeting one}

This section has already explained the observation checklist. This observation checklist was used to know the students' attitudes toward the teaching-learning activity. From the observation result during the implementation, the researcher formulated four indicators such as; the students were enthusiastic in the lesson, the students were able to follow each instruction correctly from the researcher, the students asked the researcher, the students did the task from the researcher, with two categories, they were active and passive. If the students got more than three indicators, it means the students were active, and if the students only got two to one indicator, it means the students got a passive attitude.

Based on the result of the observation checklist from the first meeting, the researcher found only 17 students who got active in the first meeting and 8 students were passive because several of the students were interested in the descriptive comic strip, many of students felt difficult to arrange word in English sentence. Much of their vocabulary used was inappropriate because had limited vocabulary. Many students made mistakes in pronunciation. So, the students were not confident to express their idea orally. The researcher found the observation checklist that the students' activeness in the teaching and learning process was not improved in every meeting. Because less than 17 students got active.

\section{The Result of the Questionnaire meeting one}

The questionnaire was used to know the response of the students about using comic strip in teaching speaking descriptive text. The questionnaire consisted of ten questions with yes and no answers, they are; (1) are you happy when you studied speaking skill in the descriptive text by using comic strip via the google meet application? (2) is using comic strip good for teaching speaking in the descriptive text? (3) is using comic strip helping you to speak descriptive well and correctly? (4) do you understand when you studied speaking skills in the descriptive text by using comic strip? (5) do you motivated to study during the teaching and learning process? (6) is the lecturer's instruction clear during the teaching process? (7) is comic strip appropriate in teaching speaking in the descriptive text? (8) do you prefer to use the comic strip as a media in teaching speaking especially in the descriptive text? (9) according to your opinion, is there any advantage you get when join in teaching speaking descriptive text by using comic strip? (10) do you feel easy when you did the assignment? 
Table 1

The Result of Questionnaire of Students' Attitudes

\begin{tabular}{|c|l|c|c|c|}
\hline No. & \multicolumn{1}{|c|}{ Questions } & Yes & No & Total \\
\hline 1. & $\begin{array}{l}\text { Are you happy when you studied speaking skills in the descriptive text } \\
\text { by using comic strip? }\end{array}$ & 21 & 4 & 25 \\
\hline 2. & Is using comic strip good for teaching speaking in descriptive? & 20 & 5 & 25 \\
\hline 3. & $\begin{array}{l}\text { Is using comic strip helping you to speak descriptive text well and } \\
\text { correctly? }\end{array}$ & 21 & 4 & 25 \\
\hline 4. & $\begin{array}{l}\text { Do you understand when you studied speaking skills in the descriptive } \\
\text { text by using comic strip? }\end{array}$ & 20 & 5 & 25 \\
\hline 5. & $\begin{array}{l}\text { Do you get the motivation to study during the lecturer and learning } \\
\text { process? }\end{array}$ & 19 & 6 & 25 \\
\hline 6. & Is the lecturer's instruction clear during the teaching process? & 20 & 5 & 25 \\
\hline 7. & Is comic strip appropriate in teaching speaking in the descriptive text? & 18 & 7 & 25 \\
\hline 8. & $\begin{array}{l}\text { Do you prefer to use comic strip as a media in teaching speaking } \\
\text { especially in descriptive text? }\end{array}$ & 18 & 7 & 25 \\
\hline 9. & $\begin{array}{l}\text { According to your opinion, is there any advantage you get when join in } \\
\text { teaching speaking descriptive text by using comic strip? }\end{array}$ & 21 & 4 & 25 \\
\hline 10. & Did you enjoy when you did the assignment? & 21 & 4 & 25 \\
\hline & Total & $\mathbf{1 9 9}$ & $\mathbf{5 1}$ & $\mathbf{2 5}$ \\
\hline & Average & $\mathbf{1 9 . 9}$ & $\mathbf{5 . 1}$ & $\mathbf{2 5}$ \\
\hline
\end{tabular}

From the result of the questionnaire conducted in meeting one, the researcher got 19.9 "yes" and 5.1 "no" included students who were absent in meeting one. So, the students answered the questionnaire with 19.9 or 20 students who had a positive response. It means more than 19 students had positive answers. The researcher found from the result of the questionnaire that students' responses in teaching-learning by using comic strip had a positive response.

The use of comic strip as media in teaching speaking descriptive text can promote students' speaking skills. The researcher used the test as an instrument to assess the students' speaking skills. The test was conducted on January $4^{\text {th }}, 2021$. It was an individual test given to the students in oral form. The researcher asked the students to describe comic strip. Then the researcher asked some questions related to the comic strip that had been described to measure their understanding. Before the students presented to describe comic strip, the researcher allowed them to make a brief note of their characteristics to drill for the descriptive text for about 20 minutes. They were only allowed to see the comic strip as a guide for their speaking.

From the result, the researcher found 22 students got scores less than 75 . It means that only $88 \%$ of students could achieve the standard score. From the result, the researcher also found that students had poor vocabularies, difficulties in arranging words into a sentence, poor pronunciation, and low confidence.

\section{Meeting II}

Meeting two was implemented on January $11^{\text {th }}, 2021$. The researcher presented a different theme. The theme was about room service restaurant. In meeting one a few students still had a poor vocabulary, their pronunciations were still poor and few of them had lees confidence to speak up in front of the class. Based on the problem that appeared in the meeting one, the lecturer could solve the problem which was found. The lecturer guided the students in pronunciation. The researcher invited the students to go around to see the comic strip. So, they could easily choose vocabulary which appropriated to describe the comic strip. The researcher also used the reward for making the students more motivated to speak up. the 
lecturer who was teaching speaking of descriptive text by using comic strip with applying different object of learning, giving brainstorming, and practicing in a group they also consisted of teaching-learning items such as; the material, the media, and the course agreement. The material was descriptive and the theme was room service restaurant. The media, based on the title of this research, the researcher choose comic strip as media in teaching descriptive text. The course agreement was prepared by the researcher for presenting the material, consists of (a) the subject, class, semester, academic year, and time allotment, (b) the objective of the lesson that was at the end of the teaching and learning process, the students were able to get information from what the lecturer showed by comic strip and the students were able to speak up on descriptive, (c) the teaching-learning process was divided into some phases, they were opening, main activity, and closing, (d) the source was taken from a book and internet, (e) The oral test was chosen by the researcher as the evaluation.

\section{Pre Activity}

This activity was carried out in 15 minutes. Like in the first meeting, there were three steps in this section. In the first step, the researcher asked the students to pray together. Then, she greeted the students and checked the students' attendance. After that, the researcher informed the objective of the lesson and stimulated the students about the topic that would be discussed and the media that would be used.

\section{Whilst Activity}

Whilst activity was carried out in 65 minutes, whilst activity divided some parts first, the researcher gave brainstorming by using comic strips about room service restaurant about vocabularies which related to the lesson. Second, the researcher asked the students to make some groups based on students' preferences to look for the restaurant service related to room service. After that, the researcher gave the task by answering the guiding question based on the worksheet. Next, the researcher asked some students to describe their assignments. In the last section, the researcher gave corrections to their description.

After giving brainstorming, the researcher continued whilst activity by explaining the role of the test. Then, the researcher asked the students to make some groups based on their preference then the students should look for their turn to speak up about room service restaurants related to their preference. In the last whilst activity, the student's described orally the comic strip in online google meet without seeing the notes.

\section{Post Activity}

This activity was carried out in 10 minutes. In this activity, the researcher concluded the lesson and gave reinforcement to the students by announcing their scores and giving any suggestions to the students.

\section{The Result of the Observation Checklist meeting Two}

In this case, the researcher used some instruments to know about the student's attitude toward the use of comic strip as media in this study. The instruments were observation checklist, questionnaire, and the students' achievement or result of the students' test that each of them.

From the observation result during the implementation in meeting two, the researcher formulated four indicators with two categories, they are: the students were enthusiastic in the lesson; the students were able to follow each instruction correctly from the researcher; the students asked the researcher; the students did the task from the researcher and the categories are active and passive.

Based on the result of the observation checklist from the first meeting up to the last meeting the data in enthusiasm were very good, the students' activeness and their fluency in 
answering the researcher questions increased in every meeting. Moreover, they looked happy in expressing their ideas orally. The researcher found only 23 students were got active and 2 students were passive in the second meeting.

\section{The Result of the Questionnaire Meeting Two}

The questionnaire was used to know the response of the students about using comic strip in teaching speaking descriptive text. The questionnaire consisted of ten questions with yes and no answers, they are; (1) are you happy when you studied speaking skill in the descriptive text by using comic strip? (2) is using comic strip good for teaching speaking in the descriptive text? (3) is using comic strip helping you to speak descriptive text well and correctly? (4) do you understand when you studied speaking skills in the descriptive text by using comic strip? (5) do you motivated to study during the teaching and learning process? (6) is the lecturer's instruction clear during the teaching process? (7) is comic strip appropriate in teaching speaking in the descriptive text? (8) do you prefer to use the comic strip as a media in teaching speaking especially in the descriptive text? (9) according to your opinion, is there any advantage you get when join in teaching speaking descriptive text by using comic strip? (10) do you feel easy when you did the assignment?.

Table 2

The Result of Questionnaire the Students’ Attitude in Meeting II

\begin{tabular}{|c|l|c|c|c|}
\hline No. & \multicolumn{1}{|c|}{ Questions } & Yes & No & Total \\
\hline 1. & $\begin{array}{l}\text { Are you happy when you studied speaking skills in the descriptive } \\
\text { text by using comic strip? }\end{array}$ & 23 & 2 & 25 \\
\hline 2. & Is using comic strip good to teach speaking in descriptive? & 22 & 3 & 25 \\
\hline 3. & $\begin{array}{l}\text { Is using comic strip helping you to speak descriptive text well and } \\
\text { correctly? }\end{array}$ & 23 & 2 & 25 \\
\hline 4. & $\begin{array}{l}\text { Do you understand when you studied speaking skills in the } \\
\text { descriptive text by using comic strip? }\end{array}$ & 24 & 1 & 25 \\
\hline 5. & $\begin{array}{l}\text { do you get motivation to study during the lecturer and learning } \\
\text { process? }\end{array}$ & 21 & 4 & 25 \\
\hline 6. & Is the lecturer's instruction clear during the teaching process? & 20 & 5 & 25 \\
\hline 7. & $\begin{array}{l}\text { Is comic strip appropriate in teaching speaking in the descriptive } \\
\text { text? }\end{array}$ & 23 & 2 & 25 \\
\hline 8. & $\begin{array}{l}\text { Do you prefer to use comic strip as a media in teaching speaking } \\
\text { especially in the descriptive text? }\end{array}$ & 21 & 4 & 25 \\
\hline 9. & $\begin{array}{l}\text { According to your opinion, is there any advantage you get when } \\
\text { join in teaching speaking descriptive text by using comic strip? }\end{array}$ & 24 & 1 & 25 \\
\hline 10. & Did you enjoy when you did the assignment? & 23 & 2 & 25 \\
\hline & TOTAL & $\mathbf{2 2 . 4}$ & $\mathbf{2 6}$ & $\mathbf{2 5}$ \\
\hline & Average & $\mathbf{2 2 . 4}$ & $\mathbf{2 . 6}$ & $\mathbf{2 5}$ \\
\hline
\end{tabular}

From the result of the questionnaire conducted in meeting two, the researcher found 22.4 answered "yes" from 10 questions which gave to 25 students. So, it means more than 22.4 or 25 students who had positive answers. The researcher found from the result of the questionnaire that students' responses in teaching-learning by using comic strip in meeting two had a positive response.

The researcher used the test as an instrument to assess the students' speaking skills. The test was conducted in the second meeting on January $14^{\text {th }}, 2021$. It was an individual test given to the students in oral form. The researcher asked the students to describe comic strip one. Then the researcher asked some questions related to the comic strip that had been described to measure their understanding. Before the students presented to describe comic 
strip, the researcher allowed them to make a brief note of their characteristics to drill for the descriptive text for about 20 minutes.

From the result, the researcher found that only 2 students got scores less than 75 . It means the result $92 \%$ of the students could achieve the standard score. So, the criteria of success were reached. The lecturer used the comic strip to teach the students' speaking skills in descriptive text. The test was used by the researcher as an instrument to assess the students' speaking skills in descriptive text.

The use of comic strip can motivate the students' enthusiasm, activeness, and speaking scores. The students had a positive attitude of their enthusiasm, activeness, also their feeling, and their scores also improved. In this section, the result of this research was discussed based on the relevant theories under the study in the use of comic strip to increase speaking skill in the descriptive text of the tourism business management of Politeknik Negeri Banyuwangi.

\section{Discussion}

This part would present the result of the data analysis. It correlated the result and the theories. During the implementation from the observation of this research in meeting one, the result of the students' average score was 76 so it was above the criteria of success. It has happened because the lecturer had prepared well before she began the teaching and learning activities. Besides, the students were interested in the teaching and learning process. The students' speaking skill was very effective. Liu (2004) said that using comic strip is one of the very helpful media in producing words because the students can see the thing directly, the students can see, touch, and memorize the object well. So, they are able to use appropriate vocabulary in speaking.

In meeting two, the lecturer gave brainstorming, and practice in a group topic of learning. She gave more attention and guidance to the low learners in class. The learning activity using the comic strip to teach the students' speaking skills in descriptive text and gave positive effects to the students. It is in line with Merc (2013) that using comic strip in teaching speaking can help the students improve their speaking skills in almost the four speaking elements (pronunciation, content, vocabulary, fluency). And using comic strip can stimulate the students to be more active in speaking lessons.

The lecturer had two meetings and the students got more vocabulary and they could arrange their ideas effectively. Every meeting, the students got the different object of descriptive text. Furthermore, the students' activities in two meetings. from the criteria of success in speaking was above 75 . In the observation checklist, students who were actively improved from the first day. Moreover, the students' responses were positive about the teaching and learning process using comic strip.

\section{CONCLUSION}

Based on the findings in the discussion, the researcher found that the lecturer used comic strips as media via the google meet application to teach the speaking descriptive text. She could run the teaching and learning process well because the lecturer had prepared the teaching preparation well such as learning agreement, media, source, and evaluation sheet. The students were able to learn speaking skills well in the descriptive text by using comic strips as media in the teaching-learning activities and it can give many advantages to the students as well as the lecturer. There were many advantages of using comics strip, first, the students could describe the hotel room services and facilities easily because they could see the characteristics of the hotel environment in the comic strip. It made the students be more confident to speak up about their idea. Second, the lecturer could be made it by herself, it was very simple, easy and cheap. Third, the lecturer got students' interest by showing the comics strip because it very colorful and they could see it without asked them to imagine it. 


\section{REFERENCES}

Arikunto. (2008). Penelitian Tindakan Kelas. Jakarta: Rineka Cipta.

Bodgan, C. R., \& Biklen, S. K. (2007). Qualitative Research for Education (4 ${ }^{\text {th }}$ Ed.). Boston: Ally and Bacon.

Brown, D. (2007). Teaching by Principles an Interactive Approach to Language Pedagogy. San Francisco: Longman.

Creswell, J. W. (2013). Qualitative Inquiry and Research Design Choosing among Five Approaches (3rd Ed.). United States of America: SAGE Publications Ltd.

Harmer, J. 2007a. How to Teach English. Essex: Longman Person.

Harmer, J. 2007b. The Practice of English Language Teaching Essex: Longman Pearson.

Liu, J. (2004). Effects of Comic Strips on L2 Learners' Reading Comprehension. TESOL Quarterly, 38(2), 225-243. https://doi.org/10.2307/3588379.

Merc, A. (2013). The Effect of Comic Strips on EFL Reading Comprehension. Eskisehir: International Journal on New Trends in Education and Their Implications. 4(5). 54-64.

Nunan, D. (2003). Practical English Language Teaching. International Edition, McGrawHill, Singapore, 88.

Susanto. (2010). Konsep Penelitian Tindakan Kelas Dan Penerapannya. Surabaya: Unesa Universty Press. 